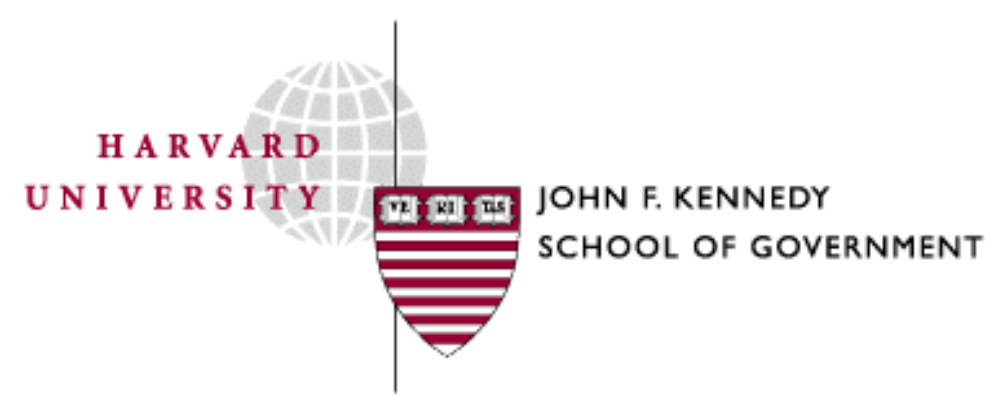

Faculty Research Working Papers Series

\title{
Advisors to Rulers - Or, What the Kennedy School of Government Can Learn from Chinese Scholar-Officials, and Vice Versa
}

\author{
Kenneth Winston
}

February 2005

RWP05-018 belongs to the author(s). Papers may be downloaded for personal use only. 
KSG Working Paper

February 22, 2005

\title{
Advisors to Rulers
}

\section{Or, What the Kennedy School of Government Can Learn from Chinese Scholar-Officials, and Vice Versa}

\author{
Kenneth Winston \\ Lecturer in Ethics \\ Kennedy School of Government
}

\begin{abstract}
In 2001, China's Ministry of Education launched a new graduate program in public administration at twenty-four universities around the country, with the explicit goal of improving management and policy-making skills in the public sector. From the beginning, these professional training schools sought guidance on curriculum design and educational organization from comparable schools in the United States, such as Harvard's Kennedy School of Government. For understandable historical and political reasons, they failed to explore their own Confucian past, to draw lessons from a critical examination of the traditional role of "scholar-officials" in Chinese government. This paper suggests, however, that only by integrating the technocratic aspects of a KSG education with the ethical orientation of scholar-officials can the Chinese provide for the requisites of public administration in a future democratic society.
\end{abstract}

An initial draft of this working paper was presented to the Harvard faculty seminar on "The Professions in Asia,” May 13, 2003. A substantially revised draft was presented at a conference on "The Professions and Professionalism in China," sponsored by the Asia Center of Harvard and the East Asian Legal Studies program at Harvard Law School, January 29, 2005. For extended comments on these drafts, I am indebted to William Hsiao, Benjamin Liebman, Jane Mansbridge, Eric Orts, Zhang Qi, and especially William Alford, who has been a continuing source of inspiration and encouragement as well as intellectual guidance. 
From the $7^{\text {th }}$ century to the dawn of the $20^{\text {th }}$, certain intellectuals in China, commonly known as scholar-officials, constituted an indigenous profession of great social importance. Other more familiar professions, such as law, medicine, and engineering, arose relatively late, largely in response to and in imitation of Western models. Indeed the pattern of development in China displays almost an inverse trajectory—steps to de-professionalize scholar-officials were taken in the early $20^{\text {th }}$ century, especially by members of the May $4^{\text {th }}$ movement, just as other professions were beginning to establish themselves. But many Chinese intellectuals continued to adhere to the scholar-official ethos through much of the $20^{\text {th }}$ century, as advisors and ministers to one or another autocratic ruler of a strong centralized state.

In the 1990s, the professional conception began to break down, perhaps irretrievably. Intellectuals who otherwise might have followed the scholar-official model adopted alternative career paths as academics, commercial writers, political activists, or government technocrats. Each of these paths involves abandonment of a distinctive feature of the traditional role: serving as a moral advisor to rulers. Should we, or the Chinese, care about this development? Many would argue there is nothing to regret because the traditional conception was deeply flawed, for two reasons: (1) the absence of professional autonomy in the advisory role, which relied primarily on moral exhortation to restrain and guide the exercise of autocratic power, and (2) the underlying assumption by these scholar-officials that, in virtue of their Confucian education, they possessed a kind of expertise in ethics, especially the ethics of governance-problematic enough in autocratic regimes but especially so in a democracy. 
These issues are of interest in themselves, but they have renewed salience with the recent emergence in China of new schools of public administration intended to train the future mandarin elite—a group that any polity, whether autocracy or democracy, needs to train well if it wishes to govern well. A central question about this training is whether it will involve anything like the ethical core of the traditional preparation for government service. And if it does, will the new mandarins be able to guard themselves any better than their predecessors against the danger of corrupted professional judgment that comes from close association with the wielders of political power? To set the context for addressing these questions, I begin with a brief account of the scholar-official role and then consider the character of scholarofficial professionalism and the place of ethics in their education.

\section{[I] Chinese scholar-officials}

In a broad sense, the term "intellectual” [zhishi fenzi, "knowledgeable elements”] refers to anyone with advanced education, including primary and secondary school teachers, doctors, engineers and scientists, academics, as well as free lance writers, artists, and musicians. In a more specific sense, the term refers to traditional scholar-officials [shi or shi$d a-f u]$ and their contemporary equivalents. My focus is on this group, a specific body of intellectuals vested with ethical responsibilities in the political realm. ${ }^{1}$

Scholar-officials were a self-conscious, educated elite who took it as their highest calling to enter government service, typically in the central bureaucracy or in provincial administrations. As humanists steeped in the moral wisdom of the past (i.e., the classic Confucian texts), they devoted themselves to protecting traditional values in the political realm: serving as the conscience of rulers—counseling them through moral suasion, 
remonstrating with them to rectify defective policies, chastising them for personal failingssometimes at great personal risk. They offered a moral compass, based on learning and reflection, and acted as critics, moral educators, and disinterested proponents of the public good. That, at least, was the ideal. Given the strong grip of Confucianism among the ruling elite, these authoritative interpreters of the classics were often a potent force in policy making, especially when they agreed among themselves and could speak with a single voice.

Scholar-officials met most of the standard criteria of a profession. They constituted a distinct social category with a collective identity and a shared ethos, including the commitment to protect and promote an important public value. ${ }^{2}$ Their rigorous examination system, effectively implemented during the Tang dynasty and refined during the Song, established them as masters of an intellectual tradition, an esoteric body of knowledge that, in its application, required complex judgment. This body of knowledge defined an educational curriculum for recruiting and training members of the profession, as well as standards of "best practice" for governance itself and hence the advice that rulers should receive. According to some scholars, the Tang dynasty innovators were the first to emphasize close study of classic texts and demonstration of literary skills as criteria for political appointment, to replace the practical training and administrative experience that had been mainly employed during the Han dynasty. Thus, scholarly merit displaced merit demonstrated through an apprenticeship. ${ }^{3}$ Sometimes, the examinations included "policy questions," but these were often viewed with alarm since they appeared to invite criticism of current practices and could be used by examiners remote from the capital to recruit dissident candidates for the bureaucracy. ${ }^{4}$ Being educated to the responsibilities of office, scholar-officials acted as intermediaries between the government and the people—guardians of moral standards and 
arbiters of public affairs, guiding rulers toward a more decent society for all. In this way, scholar-officials fulfilled the standard function of mandarin elites, providing legitimacy to the regime they served while reciprocally setting constraints, or at least articulating standards of constraint, for the exercise of political power. This privileged alliance with rulers, which depended not on caste or inheritance or political constituency but on examinations, gave them an enhanced status, and they were generally held in high esteem. (Legal privileges for scholar-officials typically included exemption from corvee labor, military duty, and various taxes.)

The professional ideal to which these "worthies" were committed was promoting humane governance or right rulership. This was not just a matter of assessing the soundness of specific public policies, although it was certainly that, but also attending to the quality of the leader's conduct and interactions with others, viewing political relationships in their moral dimension. (Since the emperor was the link between heaven and earth, his moral character and conduct were critical to the well being of society.) Thus, a specific policy, such as a declaration of war, could be evaluated strategically but also by how it reflected upon the character of the emperor or the nation — with appropriate bellicosity, for example, to uphold and not compromise Chinese honor. Humane governance did not presuppose social equality. Superiors and inferiors could act humanely to one another, because good order is sustained through fidelity to right relationships. Penal law established a baseline for what it means to be human, the minimally acceptable. But most conduct is guided by the rules of propriety [li] that define ideal human associations. They refine the moral nature of persons beyond the minimum and enable it to flourish. 
On one reading of Confucius [Kongzi], the ruler's principal function is to govern by setting an example. Governance does not consist in policy innovation to better achieve collective goals, let alone imposition of the ruler's wishes, but in inspiring subjects to perform their preordained social tasks and seek moral perfection as best they can. One reigns by being a person of good character and following the rules of propriety. (In governing, "just desire the good yourself and the common people will be good."5) The leader does not command or coerce but elicits respect and imitation by exemplary conduct. Subjects do not obey the ruler; they show deference and loyalty. They express their gratitude to the leader by making their own contribution to society, as the leader makes his or hers. Within a network of interdependent roles, each contributes to the larger civilizing enterprise.

In practice, however, China's rulers were active policy makers and used all of the standard techniques of autocratic government to get their way, as best they could. In relation to scholar-officials, it is especially noteworthy that, while ranking in the palace examinations was the key determinant of placement in the bureaucracy, a scholar-official's actual influence (whatever his official position) depended on the emperor's personal conferral of power. Some of the techniques of imperial control included periodic circulation of officials (to prevent the development of local power bases or indispensable centers of expert knowledge), manipulation of the channels of social mobility (for example, by setting regional quotas in the examination system), and monitoring bureaucratic activity through internal intelligence agents. ${ }^{6}$ Scholar-officials, in turn, employed their own set of techniques, particularly memorials and petitions to the throne, as official monitors of imperial conduct in the exercise of loyal remonstrance [zheng]. Over their long history, remonstrants were not always located in a specific office in the imperial government but were, at various times, attached to 
chancelleries, secretariats, or the censorate. For the most part, remonstrance was not a distinct public function, even when an official carried the title "Grand Remonstrator," but an activity that many functionaries could engage in. Charles Hucker observes that the very existence of specialized mechanisms for remonstrance was premised on the fallibility—and corrigibility— of the ruler. But not all rulers accepted this implication. Certain Ming rulers were especially notorious for their intolerance of criticism, yet "many censorial—and other—officials in the Ming dynasty nevertheless withstood emperors to their faces in the best Confucian manner [which] testifies to the vitality of the tradition.,"7

One might expect that, as the scholar-officials were sometimes conduits to rulers of information about the state of the realm, so they would be conduits in the opposite direction, educating commoners about regime policies and moral conduct. Some traveled the lecture circuit, speaking to local groups around the country with the aim of moral edification and inculcating deference to the state. Some wrote didactic novels or poetry; others took up general social criticism, including criticism of deviant forms of Confucianism. But movements toward popularizing learning were sporadic at best. It was only in the early $20^{\text {th }}$ century, after the collapse of the dynastic system, that the practice of writing in vernacular Chinese, rather than the inaccessible, archaic classical language, became more urgent. This shift did not change the fact that scholar-officials constituted and controlled a privileged sector of society, even as they took themselves to transcend class interests and serve the larger polity.

In the late $19^{\text {th }}$ and early $20^{\text {th }}$ centuries, the traditional Confucian sense of responsibility for the fate of society was supplemented by the belief that scholar-officials could be agents of national salvation. This newfound mission grew substantially after the 
Japanese military victory in 1895, but was conjoined, ironically, with general doubts about the adequacy of their own cultural resources to carry it out. Many intellectuals repudiated Confucianism and opened themselves to Western ideas (science, democracy, human rights), although commitment to them was highly pragmatic and often equivocal, as reflected in the maxim of the "self-strengthening” movement: “Chinese learning for essential principles, Western learning for practical function.” Efforts at modernization also included adoption of Western models of professionalization, at least for such fields as law, medicine, architecture, and engineering. ${ }^{8}$ In fashioning a new self-conception, some scholar-officials no doubt became aware of the common Western view of the intellectual as an outsider, an alienated social critic, distrustful of those in power and averse to the nitty gritty of politics. ${ }^{9}$ But this view did not attract many intellectuals in China.

From the perspective of rulers, the history of China in the $20^{\text {th }}$ century is one of continual oscillation between welcoming intellectuals in the enterprise of governance and repressing the apparently subversive forces they unleashed. Yet, the ideal of professional vocation—of an elite group dependent on political favor but charged with serving as tutors of the ruler's civic responsibilities—-persisted despite the almost insuperable obstacles posed by successive governments, especially the cycles of repression in the Mao period. MarxistLeninism appealed to Chinese intellectuals for being simultaneously Western and antiimperialist, thus supporting the fierce nationalist sentiment against the Japanese. The idea of an enlightened vanguard, prepared to lead the benighted masses, matched their sense of vocation. As Tu Weiming observes, Communism was "neither the result of an international conspiracy nor a domestic misunderstanding, but was a deliberate ideological choice.” In remaining the government's collaborators, despite repeated anti-intellectual campaigns, 
intellectuals saw themselves as full-fledged participants in national reconstruction and "not ideologically alienated." ${ }^{10}$ Accordingly, they were eager to have access to inner circles of the Party, when they could, and had considerable influence. They were ready to support the regime in power, understanding, as traditionally, that politics rightly belongs to the educated. Their constant hope was that they would have sufficient influence to bring about humane reforms.

Many of the students at Tiananmen Square in 1989 shared this professional ideal. Although advocates of democracy [minzhu, "rule of the people"], what some of them meant was that government should serve the interests of ordinary people, not necessarily that ordinary people should control the government. The educated elite have a duty to guide even democratic government, especially by monitoring and, when appropriate, remonstrating with government officials to do what is right. The elite cultivate the public discourse of democracy, serve as the vanguard of social justice, and act "as watchdogs for government accountability, proposers of policies, interpreters of the demands and desires of the inarticulate masses.” China's problem, it was thought, is not just economic underdevelopment but a cultural crisis that called for contributions "that intellectuals alone could make." ${ }^{11}$ In this regard, we can trace a connection to the beginning of political discourse in $20^{\text {th }}$ century China, starting with the admonitions of Sun Yatsen in 1905 on "the necessity of political tutelage," which was "perhaps the first conscious advocacy among the leaders of Asian nationalism of 'guided democracy.",12 For many students at Tiananmen Square, freedom to speak out without adverse repercussions was more important than electoral politics. ${ }^{13}$ 
Beginning in the 1980s, and especially after 1989, many intellectuals began to pursue different routes. According to Joseph Fewsmith, these shifts were accompanied (perhaps caused) by shrinking income and declining esteem. ${ }^{14}$ Some chose to join the government as "policy wonks," that is, technocrats who abandoned the traditional generalist, moralitybearing role of the scholar-officials. Others became academics and undertook specialized research with little, if any, political relevance. Still others began to exercise the option of independence from government by becoming commercial writers, made possible by the proliferation of media along with weakened state authority. These shifts in self-conception undermined the intellectuals' role as moral standard-bearers in Chinese society and agents of political change, and they began to disintegrate as an identifiable social group. ${ }^{15}$ With the legacy of the repudiation of Confucianism, and then the collapse of Maoism, many intellectuals who continued to press for political reform oriented themselves to Western models (like their liberal "new culture" predecessors in the May $4^{\text {th }}$ movement). For others, Western liberalism is no longer the common faith. Some, especially in the younger generation, are adherents of neo-authoritarianism, at least as a transitional stage. Yet others are searching for indigenous models of governance.

In 2001, the Ministry of Education established new schools of public administration in twenty-four universities around the country, with Qinghua University in Beijing taking the lead. ${ }^{16}$ These schools were a clear departure from existing programs in public administration located in political science departments. The older programs had been introduced in the 1920s and 1930s, abandoned in the 1950s, then reintroduced in the 1980s. They emphasized theory rather than practical skills, and trained academics more than practitioners. The new programs, to the contrary, target a different audience and utilize a different pedagogy. For 
example, one requirement of admission is at least four years of work experience, and the State Education Commission has stipulated that, where appropriate, courses will use the case method of teaching and will include a credit-based internship. The explicit goal is to improve management and policy-making skills in the public sector.

The great danger in these new schools of public administration is that the "policy wonk” mentality will completely displace the scholar-official ethos. But is the traditional ethos worth saving? Is it not inherently flawed?

\section{[II] Autonomy and professional integrity}

The question so frequently faced by China's scholar-officials was whether they could fulfill their professional mission—giving moral advice to rulers—in politically adverse circumstances. Adversity extended from having no client in power—so, the advisor's counsel was not listened to, at least by anyone who mattered - to offering an unwelcome message, that is, being considered a dangerous dissenter or member of a rebellious faction. When the professional status of an occupational group is secure, a fundamental feature of professionalism — that one's colleagues are the best judges of what constitutes good adviceis not threatened. For scholar-officials, in adverse circumstances, the threats were constant. The principal vice was not sycophancy per se, although Confucius was aware of the common perception: "When a man serves his lord in complete observance of the ritual, people think he is a sycophant.” [3.18] The concern was rather corruption of judgment, which comes from a desire to maintain one’s position or influence: “Before he gets his position, his only fear is that he might not get it, and once he gets it, his only fear is that he might lose it. And when he fears to lose it, he becomes capable of anything.” [17.15] The difficulty is genuine when 
there is sufficient reason to remain in good standing with the ruler, and such reason exists when a working relationship is a necessary condition of influence. The result, however, is a legitimate worry about professional integrity.

A legitimate worry. But let us not assume too quickly that we know what integrity consists in or how it is achieved. Contemporary writers on scholar-officials, I believe, stumble on the issue of integrity, and believing that autonomy is essential to professional status, they misconstrue the composition of the professional class. The professionals we are interested in here — the scholars who served, or anticipated serving, in government as moral advisors — are slighted in favor of the occupational group from which they were drawn — the socially recognized, loosely organized, free-standing body of Confucian intellectuals. (I will refer to the occupational group as scholar-teachers, in contrast to scholar-officials.) Consider, for example, John Dardess's important study of Confucian scholars [shih] during the transition from the Yuan dynasty to the Ming. Using standard sociological criteria of professionalism, Dardess views shih as professionals only insofar as they avoided the political and bureaucratic entanglements inherent in government service. For only by such avoidance are the requisite independence, self-regulatory powers, and ability to sanction deviant members preserved. ${ }^{17}$ The difficulty is that a great many and indeed perhaps a majority of degree holders, although members of the intellectual and social elite in virtue of their success on the examinations, were not government officials and not necessarily aspirants to such positions. They set themselves up as educators, lecturers, or tutors, often for audiences ("students") who simply wished to receive instruction in Confucian thought and guidance on family life or to learn scrupulousness in personal conduct. Yet these are the figures Dardess focuses on. The result, it seems, is a portrait of a profession without clients—or at least with 
only a marginal relation to the single most important client, the ruler. Dardess's

professionals, rather, are preoccupied primarily by the task of sustaining their own existence as guardians of Confucian thought.

In presenting this picture of shih, Dardess reflects much of the sociological literature, which is given to debunking professions by regarding members as concerned more with their own fate than society's, more interested in monopolizing an occupational niche than in providing a public service. Some sociologists also exhibit a common academic distrust of government work. For example, distinguishing between "bureaucratic intellectuals" and "unattached intellectuals," Robert Merton emphasizes the frustrations felt by the bureaucratic intellectual—whose normal state, by implication, is “unattachment”—struggling with the compromises and accommodations required by bureaucratic decision making. Merton does not see bureaucratic office as having an integrity of its own. ${ }^{18}$ Similarly, political scientist Douglas Amy says that independent policy analysts, especially academics, "being freer from client and peer pressure," are better able to integrate ethical considerations into their policy advice. ${ }^{19}$ In contrast to this common view is the example of Confucius himself. As a member of a shih family of declining fortunes, he spent much of his life doing menial work. Because he could not find the employment in government he sought, Confucius ended up modeling the “wandering [unattached] intellectual” for subsequent generations. Yet, despite his failure to attain high position, Confucius did not abandon his aspirations or his self-definition. He regarded his "normal state" as that of attachment; only in government service could he fulfill his true vocation. ${ }^{20}$ His scholarly work as editor and transmitter of classic texts came only toward the end of his life, when it was painfully obvious that his political goals would remain forever unfulfilled. 
No doubt Dardess was influenced also by the writings of some of his subjects, who themselves took a highly critical view of officialdom. For many Confucians in the late dynasties, the practice of remonstrance appears to have been motivated, in part, by a deep fear that governance is inherently corrupting, that it inevitably imperils the moral person. In the words of Sung Lien, a high ranking scholar-teacher of the early Ming: "Effectiveness demands cooperation with the world, which in turn means loss of self, and loss of self means loss of virtue."21 This fear of "loss of self," of course, is not peculiar to autocratic power. Democratic governance also throws up constant temptations to the moral person, provides numerous occasions for opportunistic action, and leads to conflicts whose intractability can induce skepticism about the chances of leading a moral life in the public realm. But alienation from, or at least ambivalence toward, governance increased as the Ming dynasty endured, and it helped to foster a genre of autobiographical writing in which the classical Confucian sense of propriety and discretion gave way to harsh self-disclosure and public repentance and concerns about personal spiritual progress. ${ }^{22}$ This development created, or at least exacerbated, the divide between morality and politics. Moral reform was a matter of personal self-cultivation, an effort to achieve moral perfection in one's own life, exemplified in techniques of self-vigilance and moral bookkeeping such as the "ledgers of merits and demerits." ${ }^{23}$ The original notion that virtue finds its natural expression in sustaining right relationships in a well-ordered polity was largely lost to view. The political realm was beyond hope.

Despite Confucius's orientation to the public realm, some prominent contemporary interpreters of the tradition continue to emphasize the centrality of self-cultivation and reject the idea that public service is an essential component of the virtuous life. Thus, for Tu 
Weiming, progress in moral virtue depends on spiritual transformation—setting one’s self in order-in accordance with the eight steps of the Great Learning: "Wishing to govern their states, [the ancients] first regulated their families. Wishing to regulate their families, they first cultivated their personal lives. Wishing to cultivate their personal lives, they first rectified their hearts and minds...” Construing these steps in temporal sequence, Tu is able to imagine self-reform apart from political activity—like purifying one’s lungs without drawing a breath from the ambient air (to borrow an image from John Dewey). To be sure, even for Tu, the goal of personal moral perfection is not sought for its own sake but, ultimately, as a prerequisite for sustaining harmonious social relationships. Yet, by insisting that the virtuous person "could choose not to be involved in officialdom,” the Confucian model of selfrealization in a public vocation is conspicuous by its absence. ${ }^{24}$

Ambivalence about political life is not peculiar to Confucian scholars. It is evident, for example, in the history of Stoic thought and its oscillation between withdrawal and involvement in the world. ${ }^{25}$ In the withdrawal phase, the self-identity of the virtuous person is fashioned apart from politics. Moral integrity, it is thought, cannot depend on the vagaries of political fortune; joint action with others means only the inevitability of damaging compromise. Moral responsibility therefore extends only to what is within one's control, no further. One becomes virtuous by oneself; others are left to their fate. In this view, virtue is a function of one's ability to achieve self-mastery and is not dependent on fortuitous happenstance or the contingencies of history. In its extreme form, the Stoic "plays the Cynic" by displaying disdain for those who believe that virtue and action in the real world are compatible. 
In the involved phase, however, the Stoic sense of moral responsibility encompasses a life in politics. The isolated individual is incapable of achieving moral fulfillment- to be human is to live in political association with others. Hence, virtue requires public service. Self-mastery is still essential, but now as a necessary condition for the exercise of political authority (and with a wholly-changed content, as I will explain in a moment). In the involved phase, exemplified most forcefully in Cicero's life and writings, morality and politics are integrated, at least as an ideal. Of course, one could imagine Ming dynasty Confucians rejecting this ideal because integration of the moral and the political is compelling only when circumstances are favorable, and their circumstances were clearly not favorable. But is not good governance - the best possible governance in the circumstances—a constant need? "A gentleman [junzi] has a moral obligation to serve the state, even if he can foresee that the Way will not prevail.” [18.7] At least, many scholar-officials believed it to be so and continued their service even at great personal risk. For them, only the integrated ideal—“sageliness within, kingliness without”- served as a guide to professionals and rendered a life exemplary and worth imitating. ${ }^{26}$

It is true that promoting humane governance, like the promotion of any important social value by a professional group, may require a protected space in which special measures can be taken to sustain independent thought and judgment, to preserve precarious values against opportunism and political self-seeking. ${ }^{27}$ Too much of the history of the Chinese mandarinate is a history of slavish dependency, which is not surprising, since the emperor held a monopoly on employment (at least for the most desirable jobs) and therefore had substantial leverage for shaping the profession. Chinese rulers often insisted on flatterers even when it was in their interest to have advisors with the courage to engage in criticism. 
Even worse, in the view of emperors, were advisors who formed groups of like-minded critics; they were denounced as partisan factions. In certain periods, debate itself was regarded as divisive; the fall of the Ming dynasty was commonly attributed to factional clashes. From time to time, scholar-officials would attempt to distinguish between good and bad factions - the former committed to sound principles, the latter seeking only personal benefit and influence-but it was all too easy for emperors to fail to acknowledge the distinction. ${ }^{28}$ Since scholar-officials lacked a political base of their own, especially after the Song dynasty, they had only one another for support. In isolation, they were weak.

So, the reasons for autonomy from government are clear. At the same time, the fact that one's colleagues are the best judges of what constitutes good advice does not fail to be so just because advisors are in a weak bargaining position in relation to their client. The weakness means only that the danger of corruption of judgment is that much greater. The actual history may not have been so one-sided. Lloyd Eastman observes: “At the end of the imperial period, the literati displayed an amazing vitality and exercised an influence upon imperial policy which belie neat theories of the 'abject servility' of the officials.... [P]olicy alternatives available to the throne were limited in proportion to the intensity and uniformity of literati opinion."29

\section{[III] Toward an alternative conception of professionalism}

If the desire for power and influence can cloud the mind and divert one from righteousness, it is also true that too much disdain for worldly motives and practical problems can be disabling for moral advisors. The Analects contains contradictory opinions on these matters. Some passages observe that it is shameful to serve a leader who engages in 
wrongdoing. [14.1] If ministers stay in office, they must acknowledge their complicity and take responsibility [16.1]. (At a minimum, one should avoid complicity when there is little hope of having a good effect.) The implication is that the relationship between ruler and advisor depends on a moral meeting of minds; if the two parties cannot agree on correct principles, the relationship is at an end. However, one passage [17.7] suggests the advisor should not shy from the moral untidiness of politics; it is the only true test of one's commitment and character. And another says directly: "One cannot discard the most essential human relationships [including emperor and subject], simply to preserve one’s purity.” [18.7] According to this passage, the dichotomy between loyalty to principle and loyalty to person is too simple. As David Hall and Roger Ames observe: Character is "refined in the kiln of bureaucratic office, and such an office is an essential element in the education of the person who would be refined." 30

So, we need an alternative understanding of moral advisors as a professional group. Neither as individuals alienated from public life and intent on cultivating their own virtue, who (in Tu Weiming's phrase) “could choose not to be involved in officialdom.” Nor solely as educators, when that vocation is regarded as distinct from political engagement. The understanding we need is of advisors as conscientious public servants for whom the cultivation of virtue apart from political life is unthinkable. As a definitional matter, this alternative is captured by sociologist Wilbert Moore, whom Dardess quotes but whose point is lost. Moore says that a profession is "an occupation whose incumbents create and explicitly utilize accumulated general knowledge in the solution of problems posed by a clientele.”31 This orientation to "problems posed by a clientele" is crucial, I believe, to understanding the craft of moral advising. In general, the professional advisory role requires active (or 
anticipated) involvement in governance, for practical and epistemic reasons. Only with access to rulers, and the capacity to sustain a respectful relationship with them, is one likely to have an effect. That is the practical point. (As Confucius observes, criticism is accepted only within a relationship of trust; hence the necessity of loyal remonstrance. [19.10]) Epistemically, without actual involvement in political affairs, there is the danger of highmindedness and unrealistic moral posturing. Without knowledge of constraints and opportunities, moral reasoning is either sterile (having no real application) or artificial (producing solutions all too easily). The ruler requires practical advice.

The good mandarin integrates these dual responsibilities and thus possesses what Max Weber calls "the vocation of politics"—a vocation that most intellectuals and scholars lack. The latter conceive of themselves, from the outside, as speaking truth to power, and to them mandarins often look like opportunists or lackeys. I would suggest, rather, that the good mandarin exhibits the virtue of prudence, taking into account things as they are-the limitations of regimes, the faults of human beings, the disorder of economy and society—in order to act effectively for good in the world. Mandarins work within ideological and political constraints—-the public conscience of their time-including dominant constructs of the right way to be, say, a Marxist or a democrat. They view problems within the frame of the ruler's objectives, knowing that rulers have constituencies and political bases and face the necessity of dealing with other players. They also know that rulers attend most to advisors in whom they have the most confidence. How confidence is won depends on many factors, not the least of which is the advisor's ability to speak to the ruler's common sense and grasp of political reality. At the same time, the advisor's constant effort is to move the existing regime in a humane direction. The measure of a ruler's worth, after all, even in dark times, is the 
capacity to exploit existing opportunities to advance the public good. The good advisor advises accordingly.

Thus, the advisory role involves both dependence, in the form of political favor, and independence, in the commitment to moral principle. Is that a sustainable posture? One way to answer this question would be to examine specific cases of scholar-officials who appear to have succeeded in acting with integrity in the role, and contrast them with two types of failure - those who exhibited corrupted judgment, on one side, and those who withdrew completely from political life, on the other. Thus, if I had greater command of sources, I could consider Ou-yang Te (1496-1554) who was awarded the highest degree at an early age and eventually attained the eminent position of Minister of Rites, yet was known for his courage and outspokenness at court. ${ }^{32}$ Or I could examine the activities of scholar-officials like Wang Anshi (1021-1086) and Xu Heng (1209-1281), who managed to exercise considerable influence in less than ideal circumstances but were branded by their fellow Confucians as collaborationists—contrasting them with, say, Liu Yin (1249-1293) who repeatedly spurned the emperor's summons, was applauded by his colleagues for upholding Confucian principles, but failed to influence the court. But discussion of these cases I must leave to more knowledgeable scholars. ${ }^{33}$

An alternative approach to the question of sustainability is to consider an analogy close to home. The scholar-official's position bears a striking resemblance to certain positions in the U.S. government, such as the Solicitor General who conducts appellate litigation for the federal government. The SG is a political appointee who serves at the pleasure of the President. Although the SG is the only government official required by statute to be "learned in the law," everything the SG does is subject to formal supervision and 
direction by the Attorney General and ultimately the President, who have the legal authority to decide which cases to argue and which positions to adopt in those cases.

In practice, however, certain norms and expectations have developed that reflect an institutional commitment to the separation of law and politics. ${ }^{34}$ The first significant step toward this separation occurs in the Attorney General's office itself. Although the AG is usually a close political ally of the President and not necessarily expected to exercise undistorted legal judgment, the AG is responsible for safeguarding the legal mission of the Department of Justice and protecting it on appropriate occasions from political intrusion. (Different occupants of the office, of course, have been more or less successful in carrying out this charge.) The SG is still further removed from politics than the AG, and the control of professional norms is stronger. The SG is expected to act not just as an advocate for one side of an argument but also as a counselor to the courts, with a fiduciary duty to guide them toward dispassionate legal judgment. As this normative understanding has become entrenched, and as the best SGs have provided models of disinterested judgment, the expectation has developed that the AG will generally defer to the SG's opinion in specific legal cases. This expectation has been reinforced at the next level by the SG's high regard for the advice of the small cadre of high-quality lawyers who work in the office, where the norms of professionalism are at their strongest. This arrangement permits the virtues of the lawyerly craft to be exercised—fact-sensitivity, reasoned elaboration of legal standards over time, consistency across cases and across different areas of the law, and so on. In this way, the distinction between law and politics is sustained.

Although brief (and idealized), this description of the SG reveals a striking similarity to the Chinese scholar-official. Both are dependent and vulnerable to the whims of a political 
superior, who is nonetheless aware of background norms and expectations that require deference. Both have the task of upholding independent standards, in circumstances generating strong and legitimate counter-pressures. The potential conflict of loyalties to two masters is thus inherent in the position. In practice, both the scholar-official and the SG are required to maintain an often delicate balance between a fiduciary duty to independent standards and responsiveness to a particular administration. They conduct themselves with integrity, not when they serve only one master, but when they place their commitment to one master on a par with their commitment to the other. ${ }^{35}$ If I may be permitted to paraphrase, I would say this: "When the desire to serve the ruler prevails over moral sense, you get corruption of judgment. When moral sense prevails over the desire to serve, you get ineffective fastidiousness. When the desire to serve and moral sense are in balance, you get the exemplary advisor.” [cf. 6.18]

The "two masters" formula, of course, does more to define the problem inherent in the advisory role than to solve it. But the SG analogy suggests the following resolution of the mandarin's professional conundrum—not that moral advisors themselves must be autonomous, but that they require the existence of an autonomous group that sets standards, monitors the work of advisors, and reminds them of their corruptibility. The good advisor, in a sense, mediates between the needs of clients (the rulers) and standards set by appropriate independent auditors. I accept this resolution, up to a point. It is most compelling for legal advisors to rulers, like the SG, whose work is closely monitored by independent legal professionals. It may also be plausible for science advisors and military advisors, for similar reasons. In each case, however, we should be alert to two dangers. We should not forget that the free-standing observers themselves face problems of corruptibility, whether as academics 
or practitioners or commercial writers. (No one entirely escapes, although the sources of corrupted judgment are different in each case.) More importantly, because of the luxury of their own independence, the unattached auditors may fail to give due weight to the complex responsibilities involved in serving two masters, and mistakenly (or, at least, unhelpfully) evaluate the advisor's work by the standards appropriate to their own. In fact, once we leave the Confucian context, it is not obvious who composes the appropriate standard-setting reference group for moral advisors. I return to this point in the next two sections.

Whatever the resolution, it should be clear that one way of going wrong in systems with strong executives, whether emperor or president, is to think there is only one master and hence no possible conflict of loyalties. The $12^{\text {th }}$ century neo-Confucian writer Hung Xingzi's formulation is characteristic: “[Even] though banished and out of office, [Qu Yuan] knew only love and unalterable affection for his lord; [accordingly] he completely fulfilled the duties of a minister." That is, loyalty is "a personal commitment unto death in absolute obedience to the emperor ... personal loyalty comes before loyal service to the state.”36 Similarly, albeit without the commitment to obedience unto death, former Solicitor General Charles Fried has written: Loyalty to the president "is a moral attitude ... [and] must be recognized as having intrinsic value, as being worth following for its own sake and in principle.” Fried elaborates: "First we judge a thing or a person to be worthy of our loyalty, and then—and for that reason—subordinate our will to it.... The President is entitled to loyalty conceived in just this way from those he appointed to high office.”37

This confuses personal fealty with professional allegiance. In the executive branch, it is common to identify the interests of an administration with the interests of the chief officer, the president. This is understandable, since the fortunes of the team rise or fall with the 
fortunes of the chief. However, such identification appears to preclude the possibility that the chief could betray the interests of the team and of the office, as though the chief could do no wrong. Some team members make this assumption, and for them loyalty becomes personal fealty to the leader: following the leader's wishes and attending to the leader's personal fortune. At the extreme, loyalty becomes love. ${ }^{38}$

Affection, however, is not a necessary requirement of the advisory role and perhaps incompatible with professional judgment, which is impersonal and limited to the client's service-related needs. So, while I take for granted that advisors as professionals take rulers as their clients, helping clients to achieve their (the clients') aims, I would add that "client” is ambiguous as between the office-holder and the office. (Here the distinction between nominal client and real client could be useful.) The office-holder's principal responsibilities come with the office. The advisor's role is to be guided by a grounded conception of those responsibilities—at the most abstract level, to achieve humane governance—and at the same time to do so in a way that takes into account the political realities confronted by the officeholder.

\section{[IV] Expertise in ethics}

A basic premise of the role of moral advisor to rulers is that achieving humaneness in government requires special learning. The professional claim depends on exclusive mastery of an appropriate body of knowledge and the capacity to engage in complex judgment. Ordinary people do not know Confucian principles, even if they live by them, or at least are not expert at applying them in the political realm. Further, this mastery is attained through exacting study of the classics. It cannot be acquired through trial-and-error or on-the-job 
training. Such study, presumably, increases the reliability of one's moral judgment. The moral advisor sees things aright and, if talented, can impart that perception compellingly to rulers.

Why does an education in the classics make one an expert in ethics, especially ethics in government? In the U.S., it is clear that an advanced degree in "applied ethics” does not enhance one’s moral competence or make one a better person. That is because moral competence does not come from mastery of ethical theories, classical or modern. Indeed, in terms of moral understanding, the academic study of ethics may be an obstacle. So at least Thomas Jefferson believed when he observed: "State a moral case to a ploughman and a professor. The former will decide it as well and often better than the latter because he has not

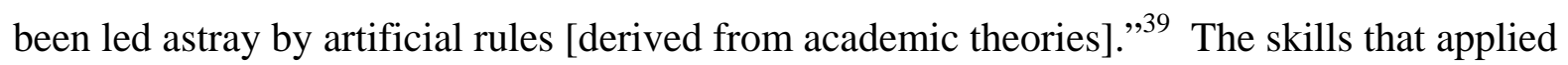
ethicists are trained in—-textual exegesis, conceptual analysis, logical evaluation of arguments - are neutral skills that presuppose no moral virtue or wisdom. Meanwhile, they lack training in history and in empirical analysis - which means that, if one aim of inquiry is to trace the consequences of a policy decision for other social values, the typical applied ethicist is at a loss how to proceed. Some observers take it as an advantage of academic ethicists that they are able to think full-time about ethics, but perhaps the opposite is true: the academic who thinks only about ethics lacks relevant experience and operates with uninformed intuitions. Detachment from the world is disabling.

When applied ethicists sit on presidential commissions (e.g., on bioethics), they often exhibit the limitations of their academic training, treating moral questions in abstraction from historical context, social facts, and political reality. They construe their task, not to represent the views of a particular constituency (serving as a public voice for an important social 
group), let alone to deliberate on the feasibility of specific policy recommendations, but to enunciate moral truth as they see it. They are very accomplished scholars, of course, and their advice is often humane. But they are scholar-teachers, not scholar-officials; policy advice is not their vocation. They easily retain their independence because they have not given up their day jobs. Indifference to practicalities, we know, can open a space for radical critique of existing policies, but also for ideological intransigence and useless abstractions. The academic, like Merton's unattached intellectual, is not constrained by the problems of a specific client, hence can take a broader view of the situation or consider a wider range of options. But these freedoms may guarantee irrelevance, at least in the near term, or entail ignorance of what exactly the problem is and which possibilities of action are open. ${ }^{40}$

The "ethics officer" attached to each U.S. government agency, advising officials on how to be ethical, exemplifies a different model. This person is typically a lawyer, well versed in existing statutes and case law and able to offer advice on what would (or would not) constitute compliance with legal rules—-where the rules for the most part have to do with conflicts of interest. An effective officer might also be sensitive to public perceptions of ethicality, employing such tests as "Would you want this act to be reported on the front page of The Washington Post?” Whatever their utility, no one would say that ethics officers are superior as moral agents or moral advisors.

How was a Confucian education different? It consisted of training not just in textual exegesis but in personal development, which is only in part a cognitive endeavor. The selfdiscipline and perseverance necessary for intellectual achievement, combined with rigorous practice in ritual ceremonies and various arts, were thought to have a salutary effect on character—enlarging faculties, broadening horizons, fostering disinterested judgment and 
commitment to the public good. (Most of the Confucian arts—ritual, music, calligraphy, archery, and charioteering — were forms of discipline for body as well as mind.) Many neoConfucians practiced "quiet-sitting" [jingzuo], a form of meditation that aimed to steady the mind and clarify thought as a prelude to right action. ${ }^{41}$ Part of the regimen during the Ming and early Qing dynasties consisted of elaborate exercises for moral improvement through selfrectification, including students confessing wrongdoing to their teachers. ${ }^{42}$ On the other hand, as I have noted, training in practical affairs or managerial skills was an underdeveloped aspect of Confucian education at least since the Tang dynasty. The various levels of examination, rigorous as they were, typically focused more on investigating the candidate's character and literary skills than determining administrative ability. Traditional scholar-officials regarded good government "more as a moral accomplishment than as a matter of managerial competence. ${ }^{43}$

The error in traditional Confucianism, I would say, is the conviction that the principal features of the good ruler are ordinary character traits, everyday virtues, rather than competences special to governance. ("If a man can steer his own life straight, the tasks of government should be no problem for him.” [13.13]) Belief in the sufficiency of good character lends itself to the idea that the root of political immorality is selfishness, callousness, vanity, or some other personal defect, and thus fosters an unhealthy preoccupation with personal moral purity and a correspondingly narrow idea of moral integrity. If self-cultivation consists in practicing in one's own life what one believes to be right, and disowning responsibility as the rest of the world goes to hell, it is also selfindulgent. Occasional expressions of moral outrage might have a therapeutic effect on the individual, but they would simply reflect the impotence of the unattached moralist. The 
asceticism practiced by some scholar-officials made sense not as a sign of withdrawal from the world but as a sign of their commitment to disinterested public service.

The traditional view is intelligible only if the work of governance is very narrowly conceived indeed; to achieve order, Emperor Shun had only to observe the rituals and face south [the traditional position of the throne], nothing more. [15.5] Thus, the scholar-official's self-conception is based on a division of labor and consequent specialization of function. Moral expertise is distinguished from technical expertise, with both thereby impoverished. Confucius knows nothing of farming, gardening, or military affairs. [13.4, 15.1] Even more, he suggests that technical competence diverts one from the Way. [19.4 $]^{44}$ Although some scholar-officials wrote handbooks on public administration, many saw an opposition between the exercise of moral leadership and the use of detailed plans and regulations. The moral leader, like the moral advisor, uses suasion and exhortation. As a result, the skills of governance suffered. This division of labor also accounts for the opposition to democracy in the Confucian tradition, because democracy places obstacles in the path of following the sageleader's insight into moral goodness. Moral advisors, similarly, would prefer to have sageemperors as their clients, because advice would be thoughtfully evaluated by the wise ruler who aimed, above all, to promote the public good. In the best of possible worlds, political factions and bureaucratic intrigue would indeed be absent, and the advisor's professional commitment to humane governance would completely coincide with the practical necessity of serving a client. ${ }^{45}$

The division of labor thus entails the predilection for top-down control, based on lack of confidence in ordinary people's abilities. Ordinary people cannot be trusted to act competently or decently. Hence, the felt need for a directive style of governance, aimed at 
compliance to goals set by rulers - an attitude, as I noted, exemplified even by some of the students at Tiananmen Square. As new schools of public policy and management (PP\&M) emerge, the worry is that they will reinforce this division of labor, separating technical from moral competence and reinforcing the directive style. Such schools are in their infancy in China, and they look to Western models. But Western schools of PP\&M have not figured out how to integrate moral and technical competence, either. They are also prone to teach a directive style of governance, although it derives from the opposite error — training for technical competence, based on good social science, but neglecting its moral and political dimensions. ${ }^{46}$

The history of PP\&M in the U.S. is a story for another occasion, but my working hypothesis is that policy analysis and strategic management developed as academic studies in detachment from the political context that gives them meaning and ought to frame their concerns. Perhaps this approach was deliberate, because (it was thought) only by bracketing moral and political concerns could PP\&M achieve professional—or, at least, academic— status. The result, at any rate, is that PP\&M appears to have the same standing as what Nathan Glazer refers to as the "minor professions" (social work, town planning, divinity, and education). Specifically, PP\&M borrows its intellectual discipline from elsewhere in the academy, deploying sophisticated analytical methods from economics and political science and purporting thereby to put PP\&M studies on a scientific footing. The ethical warrant of these methods is largely unexplored in PP\&M schools, and meanwhile the imported methods create a gap between academic teachers (who are scholars in the imported disciplines) and practitioners (who make up the student body). The teachers impart prestige to the practitioners, but the knowledge gained may have limited utility in the field. As Glazer points 
out, in the major professions (law and medicine), the prestige of the reflective practitioner who teaches is at least as great as the prestige of the academic with a doctorate. ${ }^{47}$

With a technical orientation, PP\&M programs, like other professional schools, encourage the idea that the world's problems require elite management by trained experts. Policy technocrats are presumably indifferent to political affiliation or ideology but ambitious to attach themselves to the powers that be. A pervasive strategy for avoiding the examination of values is to take them as fixed and given by a client (hence, only one master is acknowledged), or to assume a background consensus on supposedly objective values, for example, efficiency or economic growth (hence, the second master does not require serious attention). As a result, wittingly or not, technocrats serve as agents of particular interest groups or elites.

One reason for holding on to the idea that the training of advisors should be professional, not just technical, is that a professional school of PP\&M is able to take for granted a fundamental commitment to improving the practice of government. Improving practice, in turn, requires having thick relationships with practitioners and cultivating a problem-solving attitude, including the analysis of issues within a practitioner's frame of reference. The value of academic training, both in teaching and research, can be measured accordingly. Thus, with the commitment to professionalism, the scope of relevant concerns and the repertoire of relevant skills are enlarged beyond the technical; the curriculum emphasizes that policy design and managerial performance have direct and indirect effects on the quality of citizenship—not just the material well being of citizens but their attitudes, orientations, and relationships to one another. The great flaw in technocratic education is the absence of this dimension of public decision making - politics in the broadest sense. 


\section{[V] Moral advisors to democratic rulers}

How, then, do we ensure (reversing Grieder's observation) that governance is not just about managerial competence but also a moral accomplishment? This is a large topic, but I will indicate the direction of my thinking. I believe that Confucius was correct to focus our attention on virtue, and correct in thinking of virtue as a form of self-discipline, but the virtues of rulers must be rightly understood. The crucial virtues are attributes individuals have when they act in an official capacity. The "good person" is not the standard of political morality but the "good ruler." In elaborating this standard, my assumption is that the virtues of rulers and the nature of the polity are inextricably linked. What a ruler should be depends crucially on what the ruler is legitimately expected to do, and that depends on the polity. So, there are two key moves we need to make. First, let us accept the premise that humane governance is democratic — a settled part of the public conscience of our time. This premise, derived not from moral theory but from reflections on the practice of politics, forces us to reconsider what moral advice to rulers is all about. In place of the more or less coherent ethical system that Confucian scholar-officials could invoke to insist that rulers follow their advice,

contemporary advisors rely on the fundamentals of democracy. ${ }^{48}$ Second, we need to identify which attributes constitute the virtues of the good ruler in a democracy. Only with an understanding of these virtues does the advisor to rulers have a definite moral orientation.

Of course, the "fundamentals of democracy” are contested. We cannot determine what moral competence consists in apart from a specific conception of democracy. The critical debate in democratic theory at present, I believe, reflects movement in two contrary directions: toward more sophisticated ideas about "representation" and the delegation of 
authority to elites, and toward more innovative ideas about citizen participation and the exercise of local control over decision making. Both conceptions make room for governing officials with special competences, but they specify those competences very differently—and thus have very different ideas about the right relation between rulers and ruled. I believe the opportunities for greater citizen participation are almost always underestimated, but I also believe the clear trend in an increasingly integrated world is toward new forms of representation. To the extent that ordinary citizens are involved in decision making, it is through various “techniques of representation,” via interest groups, NGOs, professional experts, and other committed agents.

The trend toward representative mechanisms, it has to be said, is more consistent with the traditional assumption of imperial Confucianism that only rulers and ministers (and their knowledgeable advisors) are responsible for how things go. That tilts the debate toward guided democracy. No doubt a plausible case can be made for guided democracy, because modern society has become so complex that it appears to have outgrown the capacities of even an active, informed citizenry. However, I prefer to take as a premise the proposition that democratic self-government is too important to abandon totally to elites; the modern polity simply poses new challenges to engaging citizens actively in decision making. So, in the abbreviated remarks that follow, I shall give preference to forms of representation that embody participatory elements. In this view, good governance in a democracy encompasses not just what rulers do but how they do it. It is not just about the substance of policy; it is also, as Confucius emphasized, about the manner of governing. Relationships matter as well as policy goals, because citizens are objects of concern as whole persons. This focus grows out of the assumption that democracy is a moral order of a certain sort, based on a 
commitment citizens make to one another to answer, to their mutual satisfaction, the main question of politics: How should we live together? Accordingly, the legitimacy of rulers is sustained over time only if supported by citizens’ appreciation of official efforts to achieve orderly, fair, and decent governance.

With this orientation, certain competences special to governance take on heightened importance. Let me enumerate five virtues that I believe are essential to the good ruler and indicate quickly how they could fit into a reformed Confucian polity ${ }^{49}$ :

[1] Respect for citizens as responsible agents. A democratic conception of citizens has a double aspect; we view citizens in terms of well-being and in terms of agency. The first has to do with how well off citizens are: whether they enjoy favorable life circumstances, security, prosperity, and so on. Regarding citizens as agents means respecting their ability to set their own goals, develop commitments, pursue values_-and succeed in realizing them. ${ }^{50}$ In the context of a democratic polity, valuing agency is at the heart of self-government, recognizing the moral space within which citizens can exercise deliberate choice, typically in conjunction with others. Accordingly, the criteria of success in policy making are incomplete if they fail to take into account how policy options are likely to engage citizens. A fundamental aim of policy is to empower citizens and foster the conditions for joining in meaningful activities together-the opposite of the directive style. The good ruler aims to release human energies and create structures of opportunity.

This orientation runs counter to the dominant authoritarian strand in Confucian imperial history. Without getting into the debate over which interpretation of Confucius and Confucianism is the more authentic (not a useful argumentative tactic, in any event), it suffices to note the presence of a persistent, if minor, strand in Confucian thought over the 
centuries exemplified by thinkers who advocated non-directive, participatory modes of governance. William T. deBary has probably done more than any other U.S. scholar to draw our attention to this side of Confucianism. ${ }^{51}$ Yet it needs to be kept in mind that when Confucian scholars called for the devolution of power from the imperial court to foster local decision making and "community self-government," their expectation was that the conduct of ordinary people would exhibit moral discipline and a "common [i.e., uniform] social conscience. ${ }^{\text {} 52}$ The scholars were not calling for the exercise of moral self-definition, as we might initially be inclined to suppose (or hope). The repudiation of autocratic rule did not, and was not intended to, undercut the imperative of social harmony.

[2] Civility. A paradox of acting in the public realm is that officials lose the luxury of idiosyncratic moral conviction. Principles that are important, even foundational, to rulers in their personal lives do not necessarily have a claim on anybody else. Since public decisions affect others, often profoundly, including those with conflicting beliefs and convictions, rulers are obligated to search for grounds of action that can be generally agreed to. Accordingly, a moral capacity necessary for responsible public decision is the ability to regard one's own opinion as only one among others and not decisive simply because one holds it, even passionately. (Dewey characterizes selfishness as insisting on one's own idea of what's right regardless of consequences for others. $)^{53}$ The conscientious ruler, rather, grounds decisions in beliefs and principles that citizens generally are committed to, or could be after reflection and deliberation. The hypothetical is crucial. Assent by others need not be immediate, but it must be available. The principles invoked must be current at some level, even if only emergent and inchoate. That is why civility requires reasoning that respects the boundaries of the public conscience of one's time. ${ }^{54}$ 
The duty of civility is an expression of mutual respect among citizens as moral agents, within a self-regulating, well-ordered society. In this regard, it dovetails with the Confucian concern to foster forms of association embodying right relationships. Mutual acknowledgement as whole persons and sustained commitment to a life together, rather than transient and utilitarian relations, are features of the experience of political membership. The polity, accordingly, strives to protect the moral interest of individuals in preserving associations of the right sort. The focus on right relationships means that the self is a self-inrelation-to-others. Individuals are oriented to fellow citizens based on their shared fate. As one owes so much to them for what one is, and what one is able to do, so one has a fundamental duty to acknowledge their standing in determining the shape of a life together.

[3] Fidelity to the public good. Since a democratic polity is based on a mutual commitment to living together, the good ruler is preoccupied with determining the scope and content of the public good. This challenge is formidable because, in a democracy, almost every official gets into office via a process that incurs legitimate obligations to specific individuals or limited constituencies. At the same time, officials have a duty to enlarge their vision beyond these connections to encompass considerations of the public good. A key attribute of the good ruler, then, is the ability to reconcile partial with general perspectives. Members of a national legislature, for example, are typically elected from particular districts and have duties to their electoral constituents. But in the exercise of their constitutional powers, they are also lawmakers for the whole country and thus have responsibilities to every citizen (their constitutional constituents). Similarly, top-level administrators owe allegiance to their appointing officer and the officer's political agenda, but they are also bound to the statutorily created mandate of their office, which may or may not coincide with their 
superior's wishes. Policy advisors face this dual responsibility derivatively when they take on rulers as clients. Only judges appointed for life escape the need to grapple with it.

The task of reconciling partial and general perspectives is a test of the integrity of the good ruler. In Confucian thought, a common assumption is that individual and collective well-being form a natural harmony; they converge and require each other. Even writers of the “enlightenment” period in the early $20^{\text {th }}$ century who professed an explicit anti-Confucian stance and borrowed ideas from the West, interpreted these new ideas to support their commitment to natural harmony. Liang Qichao, for example, adopted the idea of individual rights but also accepted the stricture that no right could be inconsistent with a person's social duties. The rights one may legitimately enjoy are those that contribute to harmonious social order. ${ }^{55}$ Today, we are inclined to be skeptical about the appeal to social harmony. Individual and collective well-being too often become unglued and appear to stand in antagonistic relation. In this view, the values and interests of individuals are genuinely opposed—gain for one must mean loss for another-so harmony is achieved only by suppressing some legitimate claims. But perhaps this view is mistaken. The democratic faith, John Dewey suggests, is that disputes, controversies, and conflicts can be conducted as cooperative undertakings. Recognizing that conflict is inevitable does not require that we regard it as intractable. A polity may confront the inevitability with efforts to mitigate conflict by finding more inclusive values. ${ }^{56}$ In this process, harmony need not be assumed as pre-established but becomes a goal in social reconstruction.

[4] Proficiency in democratic architecture. A crucial ingredient of citizens' capacity to exercise moral agency is the availability of structures of collective decision making. To act effectively as a member of a democratic polity requires mechanisms that bring each citizen's 
actions into meaningful relation with the actions of others. This is the civic dimension of freedom — the institutional capacity to engage with others in self-rule and achieve a decent life together. Its realization requires considerable expertise in institutional design, especially skill in deliberative judgment about ends and means. It is this virtue that I am attempting to capture with the clumsy phrase "proficiency in democratic architecture.” The basic idea is that institutional design is moral legislation. Any specific institutional form leads us to conduct our lives one way rather than another. A given structure provides access to some agents and excludes others; it elicits some types of information and hides others; it legitimates some preferences for action and delegitimates others. Each structure provides myriad occasions for participation and choice, hence for learning and improvement. The good ruler is an architect of social structures that are decent, fair, and workable—-fashioning mechanisms for effective collaboration among citizens and establishing acceptable frameworks for their future dealings. This involves identifying the appropriate mechanism for a given type of problem, guided by the types of relationships that would obtain among citizens if it were realized.

It is important to emphasize the structural dimension of governance, and therefore what advisors to rulers need to be expert in, in light of the traditional Confucian reliance on the uncertain technique of moral suasion. The influence of scholar-officials rested on the hope that the ruler would share the aspiration to be a sage-king, which would entail openness to the advice of a wise mentor, rather than institutional infrastructure that guaranteed accountability in decision making. With democratic governance, hope alone will not do. But designing the mechanisms by which accountability occurs, and the participation of ordinary citizens in decision making facilitated, still requires the special competence that only a 
suitably trained elite will have. This provides an opportunity to give new meaning to the idea of guided democracy—while citizens generally exercise control, they do so through appropriate legal forms fashioned by architects of social structure. What we might call "the Confucianization of law" is incomplete as long as it has to do only with the content of law and not also the formal mechanisms that shape relations among citizens.

[5] Prudence. In the classical sense, prudence is the cardinal political virtue: the exercise of practical wisdom in governance. Since governance is largely about sustaining valued relationships among citizens, ruling requires more than technical expertise. It is an inherently moral enterprise. In a more specific sense, prudence is practical wisdom in deciding how to act in specific circumstances, making sound judgments in concrete situations. It is thus the capacity and willingness to engage in ethical inquiry as the occasion requires. The commitment to core values is balanced by an appreciation of recurrent perplexities and tensions. Grand principles are constrained by sensitivity to consequences for specific persons. The good ruler appreciates the fallibility of human planning and the inevitability of unintended consequences.

This idea of prudence connects to the theme of flexibility in judgment that runs through the Analects. The Master says: “An exemplary person [junzi] is principled but not rigid.” [15.37; also 4.10 and 9.4] That is, the exemplary person uses discretion, in response to changing or unanticipated circumstances in specific situations. Accordingly, it is sometimes necessary to "bend the rules" to realize the Way. This is perfectly understandable, because rules (or any particular formulation of them, as in legal codes) reflect the limits of human language and are always imperfect or incomplete in relation to what one is attempting to accomplish, such as treating people with due respect. Consequently, faithful rule-following 
depends on more general competences, such as the ability to discern the purpose of a rule and the imaginative power to appreciate what is practically possible. The good ruler has the ability to discern when rule-departure more effectively meets official responsibilities than rule-following.

The five virtues are my riff on this passage: “The practice of humanity comes down to this: tame the self and restore the rites.” [12.1] Taming the self means exercising the five virtues in public office. Restoring the rites means creating the conditions for sustaining right relationships among citizens.

The role of the moral advisor is to remonstrate with rulers about the five virtues and do so in a way that speaks to the practicalities of governance. Taking the world as it is, working within the bounds set by the principles that constitute the public conscience of a specific time and place, the prudent advisor reminds rulers of these principles, when neglected; identifies opportunities for extending, or restricting, these principles, when warranted; and articulates new principles or values that become salient in virtue of other changes in society, or points to the obsolescence of existing principles brought about by social change. As the work proceeds, it should not be assumed that rulers always have a wellformed idea beforehand of what they seek; the advisor is an active participant, helping to shape ends as much as means_-indeed, necessarily so, since ends and means interact and involve each other. At the same time, it should not be assumed that advisors always know beforehand what the right course of action would be in a given situation; as dialogue proceeds, the advisor could well learn from the ruler what promoting democratic values requires. 
Does the effort to serve two masters inevitably compromise one's integrity? Those who assume that all virtue lies on the side of principles and all vice on the side of politics may think so. That is not my position. My thesis, rather, is that the political master makes legitimate claims. (Not all of its claims are legitimate, of course; one has to do some sorting.) Is there, then, a class of people who exercise, or could exercise, this role? If so, would they be professionals? Does it matter? Perhaps what is important is not whether the moral advisor is a professional, but simply whether he or she can act with integrity—measured by success in balancing the two masters. The point is that there is a function of sufficient importance that a democratic polity has an interest in promoting its cultivation. Democracy does not just happen; it requires nourishing appropriate civic ideals and the social practices that sustain them. (Exemplars for imitation would come from the history of democracy.)

Does the moral advisor occupy a distinct role, or is this function one that any advisor could—and should—perform? If we focus only on the task of sustaining democratic values, it looks like a distinct role. But democratic values intersect with specific policies, and then it is clear that the substantive policy advisor has an extra thing to think about. For example, a core contention in the U.S. debate on welfare reform is whether the mission of a welfare office is “income maintenance” (managing clients by applying rules of eligibility, dispensing checks, monitoring activities) or "transitional assistance" (facilitating re-employment and providing means for nurturing self-sufficiency). Relationships are at stake here, not just goals.

So understood, democratic governance is a radical departure from the imperial Confucian tradition, but autocracy does not represent the only authentic Confucianism. Indeed the tradition is sufficiently rich that dissident voices have always been able to support their dissent by citing authoritative texts. As I have noted, a number of scholar-officials, or at 
least scholar-teachers, have over the centuries fashioned an alternative tradition that characterizes governance in terms of a facilitative rather than directive style. Instead of prescriptive rules or coercive threats or the manipulation of incentives from above, rulers prefer modes of governance that foster responsible agency. One does not have to engage in the rhetorical device of arguing that these are the genuine Confucian values, in contrast to the debased dynastic tradition, to appreciate that these ingredients are compatible with the Confucian text and, arguably, crucial to the flourishing of democracy.

\section{ENDNOTES}

${ }^{1}$ On the meaning of shi (or shih), see Derk Bodde, Chinese Thought, Society, and Science: The Intellectual and Social Background of Science and Technology in Pre-modern China (Hawaii, 1991), 204-205.

${ }^{2}$ Philip Selznick, Leadership in Administration: A Sociological Interpretation (California, 1984 [1957]), 120123.

3 Jack L. Dull, “The Evolution of Government in China," Heritage of China: Contemporary Perspectives on Chinese Civilization, ed., Paul S. Ropp (California, 1990), 55-85. But cf. Charles Holcombe, In the Shadow of the Han: Literati Thought and Society at the Beginning of the Southern Dynasties (Hawaii, 1994), 75-77.

${ }^{4}$ Alexander Barton Woodside, Vietnam and the Chinese Model: A Comparative Study of Vietnamese and Chinese Government in the First Half of the Nineteenth Century (Harvard 1988 [1971]), 213-214.

5 Confucius, The Analects, 12.19. For this passage, I have used the translation by D. C. Lau (Penguin Books, 1979), but all other quotations from Confucius use the translation by Simon Leys (W. W. Norton \& Co., 1997).

${ }^{6}$ Woodside, 62ff.

${ }^{7}$ Charles O. Hucker, "Confucianism and the Chinese Censorial System," Confucianism and Chinese Civilization, ed., Arthur F. Wright (Stanford, 1964), 57 and 200.

${ }^{8}$ Xu Xiaoqun, Chinese Professionals and the Republican State: The Rise of Professional Associations in Shanghai (Cambridge U., 2002).

${ }^{9}$ Edward Shils, The Virtue of Civility: Selected Essays on Liberalism, Tradition, and Civil Society (Liberty Fund, 1997), 60-61, 77, 83-84.

${ }^{10}$ Tu Weiming, Way, Learning, and Politics: Essays on the Confucian Intellectual (SUNY, 1993), 172. 
${ }^{11}$ Craig C. Calhoun, Neither Gods nor Emperors: Students and the Struggle for Democracy in China (California, 1994), 241.

12 Peter G. Rowe and Seng Kuan, Architectural Encounters with Essence and Form in Modern China (MIT, 2002), 14-15.

${ }^{13}$ See the essays by Elizabeth J. Perry and by Joseph W. Esherick and Jeffrey N. Wasserstrom in Popular Protest and Political Culture in Modern China, eds., Jeffrey N. Wasserstrom and Elizabeth J. Perry ( ${ }^{\text {nd }}$ ed., Westview, 1994).

${ }^{14}$ Joseph Fewsmith, China Since Tiananmen: The Politics of Transition (Cambridge U., 2001), 103.

${ }^{15}$ Fewsmith, 104. See also Merle Goldman, "Politically-Engaged Intellectuals in the Deng-Jiang Era: A Changing Relationship with the Party-State,” The China Quarterly (1996), 51.

${ }^{16}$ See Caroline Haiyan Tong and Jeffrey D. Straussman, "A Master of Public Administration Degree with Chinese Characteristics?,” Journal of Public Affairs Education 9:2 (2003), 105-115.

17 John W. Dardess, Confucianism and Autocracy: Professional Elites in the Founding of the Ming Dynasty (California, 1983), especially 65-67 and 84.

${ }^{18}$ Robert K. Merton, “The Role of the Intellectual in Public Bureaucracy," Social Theory and Social Structure (rev. ed., Free Press, 1957), 207-224.

${ }^{19}$ Douglas Amy, “Can Policy Analysis Be Ethical,” Confronting Values in Policy Analysis: The Politics of Criteria, eds., Frank Fischer and John Forester (Sage, 1987), 59. See also Timothy Cheek’s essay in the Wasserstrom and Perry volume, noted above, for the view that Chinese intellectuals became more professional by leaving the mandarin role.

${ }^{20}$ Benjamin I. Schwartz, The World of Thought in Ancient China (Harvard, 1985), 59. But note this passage: "The Master said: 'In the Documents it is said: "Only cultivate filial piety and be kind to your brothers, and you will be contributing to the body politic." This is also a form of political action; one need not necessarily join the government."” [2.21]

${ }^{21}$ Dardess, 164.

${ }^{22}$ Wu Pei-Yi, The Confucian's Progress: Autobiographical Writings in Traditional China (Princeton, 1990).

${ }^{23}$ Cynthia J. Brokaw, The Ledgers of Merit and Demerit: Social Change and Moral Order in Late Imperial China (Princeton, 1991).

${ }^{24}$ Tu Weiming, "Heart, Human Nature, and Feeling” (undated lecture), 15. Elsewhere Tu offers a more ambiguous picture. While the stages of development form a linear progression, they are not "merely" linear, for cultivating one's personal life "necessarily leads" to ordering state affairs and cannot otherwise be said to be fully expressed. See Tu Weiming, "Li as Process of Humanization" in Humanity and Self-Cultivation: Essays in Confucian Thought (Lancaster-Miller 1978), 28.

${ }^{25}$ Robert D. Cumming, Human Nature and History: A Study in the Development of Liberal Political Thought (Chicago, 1969), volume 1, chapter 7.

${ }^{26}$ For a critique by a $17^{\text {th }}$ century Confucian of the emphasis on individual virtue as the key to good governance, without abandoning the idea that governance is the responsibility of properly educated and certified professionals, see Huang Zongzi, Waiting for the Dawn: A Plan for the Prince, translated by William Theodore de Bary (Columbia, 1993). 
27 Selznick, 120-123.

28 Benjamin A. Elman, "Imperial Politics and Confucian Societies in Late Imperial China: The Hanlin and Donglin Academies,” Modern China 15:4 (1989), 379-418.

29 Lloyd Eastman, Throne and Mandarins: China's Search for a Policy During the Sino-French Controversy 1880-1885 (Harvard, 1967), 207 and 210.

30 David Hall and Roger Ames, Thinking from the Han: Self, Truth, and Transcendence in Chinese and Western Culture (SUNY, 1998), 156.

31 Dardess, 24. Curiously, Dardess fails to observe that his designation of scholar-officials as professionals reverses the usual patron/client construction of the relationship, by making the ruler the client. I suppose some scholars might regard this reversal as a serious distortion, based on a western model. But Dardess's conception captures something important in scholar-officials’ aspiration (their ideal self-understanding), and it provides a reading of the past, even if partial, that facilitates comparison to the present.

$32 \mathrm{Wu}, 119$.

33 For documents and commentary, see William Theodore de Bary and Irene Bloom, compilers, Sources of the Chinese Tradition ( $2^{\text {nd }}$ ed., Columbia, 1999), volume 1, 609ff., $764 f f ., 779$.

34 Kenneth Winston, “Constructing Law’s Mandate,” Recrafting the Rule of Law: The Limits of Legal Order, ed., David Dyzenhaus (Hart, 1999), 283-308.

${ }^{35}$ I owe this formulation to Philip Heymann, The Politics of Public Management (Yale, 1987), 72.

36 Laurence Schneider, A Madman of Ch'u: The Chinese Myth of Loyalty and Dissent (California, 1980), 75 and 77.

37 Charles Fried, Order and Law: Arguing the Reagan Revolution-A Firsthand Account (Simon and Schuster, 1991), 189.

38 On the literature of "the ill-fated minister" and the metaphor of political loyalty as love, see Schneider, 31-34.

39 Quoted by Garry Wills, Inventing America: Jefferson's Declaration of Independence (Random House, 1978), 203. For a similar view, see Aristotle, Nicomachean Ethics, at 1143b8-14.

40 Thus, I take issue with Ronald Dworkin's claim that “academic elaboration ... reveals the true nature or character of a moral theory.” Dworkin believes academic elaboration is the correct test because we are not concerned with "the practical adjustments required to make [the] theory manageable and efficient in politics and daily life" but rather with the question "whether we can accept [the] theory in the first place.” Placing confidence in an impractical and unmanageable theory "in the first place" is something only an academic would do. Dworkin, Law’s Empire (Harvard, 1986), 286.

41 William Theodore de Bary, Asian Values and Human Rights: A Confucian Communitarian Perspective (Harvard, 1998), 136.

42 Wu Pei-Yi, “Self-Examination and Confession of Sins in Traditional China," Harvard Journal of Asiatic Studies 39:1 (1979), 5-38.

43 Jerome Greider, Intellectuals and the State in Modern China: A Narrative History (Free Press, 1981 ), 52. Benjamin Elman suggests there is no reason to believe that an elite drawn from the gentry class would necessarily be incompetent as public managers in a preindustrial society. Non-technical Confucian learning may 
have been as suitable for government service as the classical humanist education received by elites in early modern Europe. Elman, 381.

${ }^{44}$ Edward Slingerland offers historical support for this interpretation of the text in his edition of the Analects (Hackett, 2003), 222.

45 See David Weimer and Aidan Vining, “Toward Professional Ethics,” Policy Analysis: Concepts and Practice ( $3^{\text {rd }}$ ed., Prentice Hall, 1999), 43.

${ }^{46}$ This essay itself illustrates the current academic division of labor. My own area of expertise is professional ethics, not Chinese studies. For understanding the Chinese situation, I am heavily dependent on China specialists. But those specialists, even the ones who make a career of studying mandarins, are not necessarily expert in the ethics of public administration. They, too, are dependent on others for crucial aspects of their chosen subject matter. We each are competent, it seems, to tell only part of the story.

${ }^{47}$ Nathan Glazer, “The Schools of the Minor Professions,” Minerva 10:3 (1974), 346-364. I am indebted to Brian Mandell for bringing this article to my attention.

48 This premise is accepted by Lan Xue and Zongchao Peng of Qinghua University in their working paper on the history and current state of PP\&M education in China. They observe that China’s "new era" requires "a capable, highly efficient, democratic, responsible government," staffed by highly qualified "professional public administrators." Lan Xue and Zongchao Peng, "China’s Public Administration Education: Past, Present, and Future" (draft, no date), 10.

${ }^{49}$ On the five virtues, see Kenneth Winston, "Moral Competence in the Practice of Democratic Governance," For the People: Can the Public Service Be Fixed?, eds., John Donahue and Joseph Nye Jr. (Brookings, 2003), 169-187.

50 Amartya Sen, “Well-Being, Agency, and Freedom,” Journal of Philosophy 82:4 (1985), 185-187 \& 203-208.

${ }^{51}$ For example, de Bary, Asian Values and Human Rights, noted above.

52 Philip A. Kuhn, Origins of the Modern Chinese State (Stanford, 2002), 127. See also the work of Huang Zongxi, noted above. Interestingly, the same assumption is evident in the writings of Ralph Waldo Emerson.

53 John Dewey, “Self-Realization as the Moral Ideal,” Early Works: 1882-1898, ed., Jo Ann Boydston (Southern Illinois, 1971), v. 4, 51.

54 John Rawls, The Law of Peoples (Harvard, 1999), 56.

55 See Stephen C. Angle, Human Rights and Chinese Thought: A Cross-Cultural Inquiry (Cambridge U., 2002), chapter 6 (especially 158). A similar view to Liang Qichao’s is expressed by Thomas Jefferson in his letter of January 1, 1802, to Nehemiah Dodge. See Thomas Jefferson: Writings, ed., Merrill D. Peterson (Library of America, 1984), 510.

56 John Dewey, “Creative Democracy—The Task Before Us” [1939], Later Works 1925-1953, ed., Jo Ann Boydston (Southern Illinois, 1991), v. 14, 228. 